\title{
THE RESISTANCE OF CHROMIUM-PLATED PLUG GAGES TO WEAR
}

\author{
By Harry K. Herschman
}

\section{ABSTRACT}

An investigation of chromium-plated plug gages with particular reference to resistance to wear was made. Chromium was deposited on hardened 1.0 per cent carbon steel under varying conditions so as to produce what are commonly referred to as "bright," "milky," and "frosty" deposits. The "bright" deposits were tested in both the lapped and unlapped conditions. The other two types were tested in the lapped condition only. he scratch hardness values of chromiumplate produced under these varying conditions were studied with a view toward seeking an explanation for the cause of differences in the rate of wear exhibited by the various types of deposits. Metallographic examination of the plate showed the presence of strain lines or cracks on the surfaces of the plated gages.

\section{CONTENTS}

I. Introduction

Page

II. Preparation of specimens 295

III. Hardness tests

IV. Microstructures

V. Resistance to wear

1. Testing Procedure

VI. Summary

2. Results and discussion

VII. Acknowledgments

\section{INTRODUCTION}

The many inquiries received by the bureau in regard to the effects produced on the wear resistance of chromium plate by variations in the thickness of the plate, the rate of deposition, and the general character of the surface led to the following investigation of the resistance of chromium plate to wear.

Previous investigations ${ }^{1,2}$ at the bureau on plug gages have shown chromium-plated gages to be superior in their wear-resistance to gages made of commonly used heat-treated steels. In these early studies the gages were tested in the apparatus shown in Figure 4 against (a) hardened 1 per cent carbon steel, (b) an aluminum piston alloy, and (c) pearlitic cast iron. The wear-tests reported in the present paper were all made against the pearlitic cast iron. In order to permit a comparison of the recent with the former results, the data for the early tests on cast iron are presented in Figure 1. These early results for chromium were all obtained with "bright" coatings that had been ground and lapped.

${ }^{1}$ H. J. French and H. K. Herschman, Wear of Steels with Particular Reference to Plug Gages, A. S. S. T., 10, p. 683; 1926.

2 H. J. French and H. K. Herschman, Recent Experiments Relating to Wear of Plug Gages, A. S. S. T., 12, p. $921 ; 1927$. 
Chemical compositions of steels tested (per cent)

\begin{tabular}{|c|c|c|c|c|c|c|c|c|c|c|c|c|c|}
\hline Material & C & Mn & $\mathbf{P}$ & S & $\mathrm{Si}$ & $\mathrm{Cr}$ & W & $\mathrm{V}$ & $\Delta 1$ & Co & Mo & $\mathrm{Ni}$ & $\mathrm{Fe}$ \\
\hline $\begin{array}{l}\text { Nitralloy-- } \\
\text { High-speed steel }\end{array}$ & $\begin{array}{r}0.43 \\
.75\end{array}$ & $\begin{array}{r}0.57 \\
.31\end{array}$ & 0.010 & 0.032 & $\begin{array}{r}0.31 \\
.11\end{array}$ & $\begin{array}{l}1.85 \\
3.92\end{array}$ & 17.95 & $\begin{array}{r}0.02 \\
.89\end{array}$ & 1.29 & & & & -..- \\
\hline Stellite. & 2.87 & .76 & $-\ldots$ & $-\ldots$ & .70 & 32.5 & 15.7 & .02 & & 41.1 & 0.13 & 1.12 & 4.1 \\
\hline $\begin{array}{l}\text { High-carbon high- } \\
\text { chromium iron } \\
\text { alloy }\end{array}$ & 2. 06 & .38 & .020 & .010 & .31 & 11.45 & & .03 & & & & & \\
\hline $\begin{array}{l}\text { Oil-hardening tool } \\
\text { steel }\end{array}$ & .86 & 1.17 & .021 & .010 & .21 & .51 & .41 & & & & & & \\
\hline $\begin{array}{l}1.05 \text { per cent carbon } \\
\text { steel }\end{array}$ & 1.06 & .24 & .014 & .016 & .18 & & & & & & & & \\
\hline Ball-race steel & 1.01 & .21 & .016 & .034 & .29 & 1.46 & & & & & & & \\
\hline
\end{tabular}

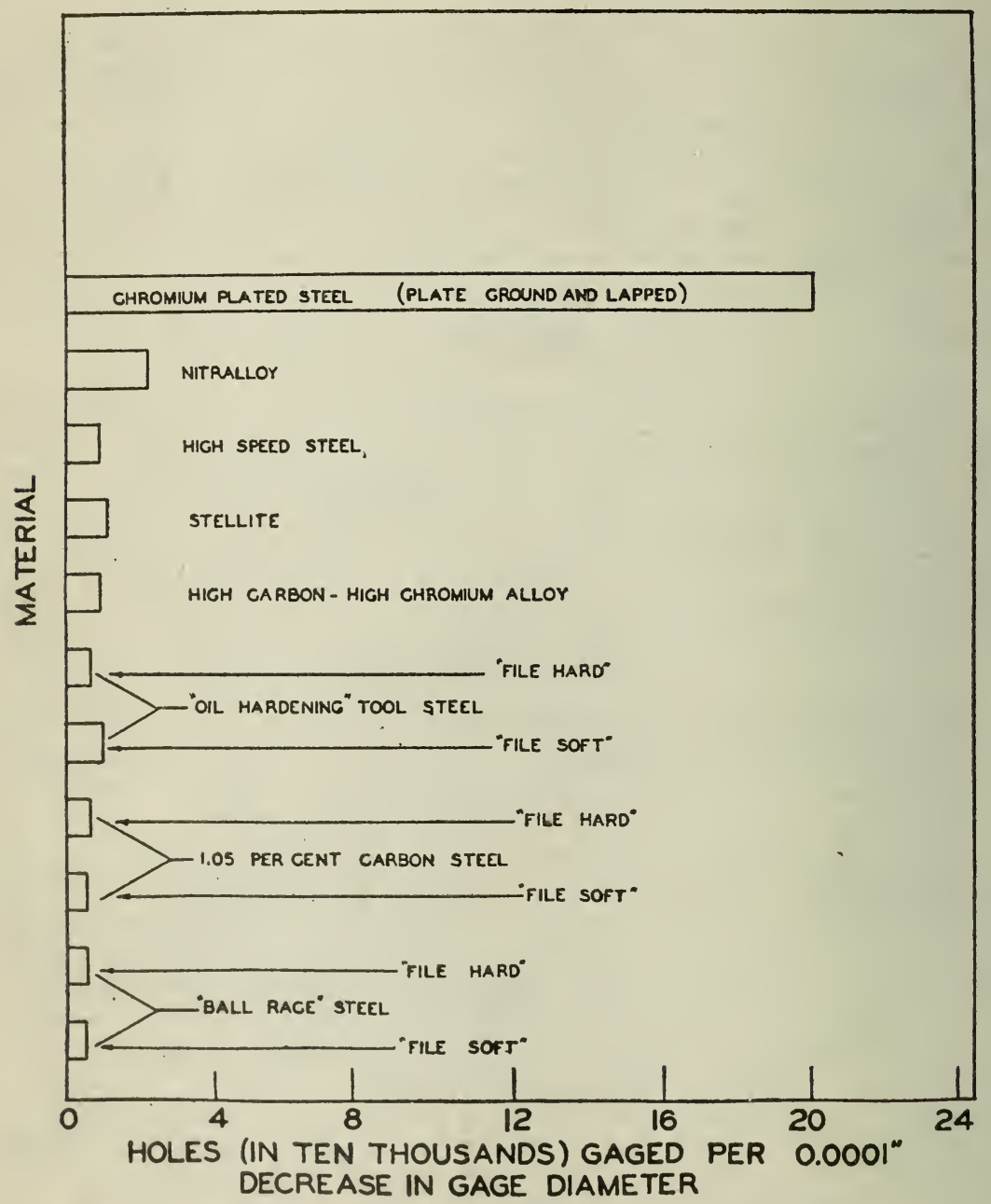

FIGURE 1.-Results of wear tests reported by French and Herschman

All tests were made against cast iron, in absence of nonmetallic abrasives. 
Subsequently, McPharlin ${ }^{3}$ reported that chromium-plated gages that are nearly smooth and free from scratches show better wear resistance than those with less smooth surfaces.

In addition to the increased wear resistance, there are other advantages to be gained in the use of chromium for plating gages, the most notable of which are: (1) The avoidance of elaborate heat treatments; (2) the reduction of warping caused by heat treating; (3) the reclamation of worn gages by replating; and (4) the avoidance or minimization of the dimensional changes caused by aging effects in master and close-tolerance gages. There are, however, limitations to the use of chromium plate, due to the fact that it can be applied uniformly only to simple forms unless special methods are used. The presence or absence of scratches on the surface of electrolytically deposited chromium will, in a large measure, be governed by the condition of the surface of the base upon which the chromium is plated.

In the present investigation, the hardness values of the chromium plate produced under varying conditions were measured with a view to explaining the difference in wear values that were obtained. Metallographic examination of the coatings was made, with particular reference to the strain lines or cracks on the surfaces of the plated gages.

\section{PREPARATION OF SPECIMENS}

The base material for all specimens was a 1.0 per cent carbon steel, quenched in water from $800^{\circ} \mathrm{C}$. $\left(1,470^{\circ} \mathrm{F}\right.$.) and tempered at $300^{\circ} \mathrm{C}$. $\left(570^{\circ} \mathrm{F}\right.$.). This treatment was designed to give a hardness of about 50 to 55 Rockwell, "C" scale. The specimens were 1.25 inches $(31.8$ $\mathrm{mm}$ ) long by 0.749 inches $(19.02 \mathrm{~mm})$ in diameter. The diameters were finished to within 0.00005 inch $(0.00125 \mathrm{~mm})$ of the above dimension. Part of these specimens were lapped by hand and part by machine. ${ }^{4}$ The surfaces of the machine-lapped gages were exceptionally free from scratches as observed with the naked eye.

The chromium-plating bath consisted of an aqueous solution of the following composition:

Chromic acid $\left(\mathrm{CrO}_{3}\right)$ $\mathrm{g}$ per liter

Sulphuric acid

3 L. M. McPharlin, The Relation of Finish to Life of Plug Gages, Am. Mach., 66 p. 775; May 12, 1927. 1 The machine-lapped bases were prepared through the courtesy of the Pratt \& Whituey C'o. 
TABLE 1.-Electroplating data

[Temperature of bath $=45^{\circ} \mathrm{C} .\left(113^{\circ} \mathrm{F}\right.$.)]

\begin{tabular}{|c|c|c|c|c|c|c|}
\hline Specimen No. & \multicolumn{2}{|c|}{ Current density } & \multirow{2}{*}{$\begin{array}{r}\begin{array}{c}\text { Plating } \\
\text { time }\end{array} \\
\text { Minutes } \\
35 \\
35 \\
40 \\
40 \\
75\end{array}$} & \multicolumn{2}{|c|}{$\begin{array}{l}\text { Measured thickness of } \\
\text { plate }\end{array}$} & $\begin{array}{l}\text { Appearance } \\
\text { of deposit }\end{array}$ \\
\hline $\begin{array}{l}47 \\
48 \\
22 \\
24\end{array}$ & $\begin{array}{r}a m p . / d m .^{2} \\
10 \\
10 \\
10 \\
10 \\
10\end{array}$ & $\begin{array}{r}a m p . / f t .^{2} \\
93 \\
93 \\
93 \\
93 \\
93\end{array}$ & & $\begin{array}{r}m m \\
0.0046 \\
.0048 \\
.0056 \\
.0058 \\
.0074\end{array}$ & $\begin{array}{r}\text { Inch } \times 10^{-4} \\
1.8 \\
1.9 \\
2.2 \\
2.3 \\
2.9\end{array}$ & $\begin{array}{l}\text { Bright. } \\
\text { Do. } \\
\text { Do. } \\
\text { Do. } \\
\text { Do. }\end{array}$ \\
\hline $\begin{array}{l}29 \\
556 \\
53 \\
36\end{array}$ & $\begin{array}{l}10 \\
10 \\
10 \\
10 \\
10\end{array}$ & $\begin{array}{l}93 \\
93 \\
93 \\
93 \\
93\end{array}$ & $\begin{array}{r}75 \\
90 \\
90 \\
150 \\
150\end{array}$ & $\begin{array}{l}.0074 \\
.0155 \\
.0155 \\
.0198 \\
.0191\end{array}$ & $\begin{array}{l}2.9 \\
6.1 \\
6.1 \\
7.8 \\
7.5\end{array}$ & $\begin{array}{l}\text { Do. } \\
\text { Do. } \\
\text { Do. } \\
\text { Do. } \\
\text { Do. }\end{array}$ \\
\hline 51. & $\begin{array}{l}10 \\
10 \\
10 \\
10 \\
10\end{array}$ & $\begin{array}{l}93 \\
93 \\
93 \\
93 \\
93\end{array}$ & $\begin{array}{l}368 \\
368 \\
919 \\
919 \\
125\end{array}$ & $\begin{array}{l}.0508 \\
.0510 \\
.1182 \\
.1102 \\
.013\end{array}$ & $\begin{array}{r}20.0 \\
20.1 \\
46.5 \\
43.4 \\
5.1\end{array}$ & $\begin{array}{l}\text { Do. } \\
\text { Do. } \\
\text { Do. } \\
\text { Do. } \\
\text { Do. }\end{array}$ \\
\hline $\begin{array}{l}27 \\
21 \\
15 \\
18\end{array}$ & $\begin{array}{r}10 \\
10 \\
10 \\
5 \\
5\end{array}$ & $\begin{array}{l}93 \\
93 \\
93 \\
47 \\
47\end{array}$ & $\begin{array}{l}125 \\
125 \\
125 \\
125 \\
125\end{array}$ & $\begin{array}{l}.013 \\
.0165 \\
.0165 \\
.0145 \\
.0216\end{array}$ & $\begin{array}{l}5.1 \\
6.5 \\
6.5 \\
5.7 \\
8.5\end{array}$ & $\begin{array}{r}\text { Do. } \\
\text { Do. } \\
\text { Do. } \\
\text { Milky. } \\
\text { Do. }\end{array}$ \\
\hline 37 11 12 & $\begin{array}{l}15 \\
15 \\
10 \\
10\end{array}$ & $\begin{array}{r}140 \\
140 \\
93 \\
93\end{array}$ & $\begin{array}{l}125 \\
125 \\
125 \\
125\end{array}$ & $\begin{array}{l}.0096 \\
.0155 \\
.0081 \\
.0071\end{array}$ & $\begin{array}{l}3.9 \\
6.1 \\
3.2 \\
2.8\end{array}$ & $\begin{array}{l}\text { Frosty. } \\
\text { Do. } \\
\text { Bright. } \\
\text { Do. }\end{array}$ \\
\hline
\end{tabular}

${ }^{1}$ Copper plated 0.0001 inch before chromium plating.

The gages were plated, one at a time, in a cylindrical glass jar about $6 \frac{1}{2}$ inches $(16 \mathrm{~cm})$ in diameter by 9 inches $(23 \mathrm{~cm})$ wide. An anode of sheet lead was placed about the entire inner periphery of the jar. The plating solution was maintained at a temperature of $45^{\circ}$ C. $\left(113^{\circ} \mathrm{F}\right.$.) during the plating operation. The gages before plating were immersed for about 10 seconds in an electrolytic cleaning bath which consisted of an aqueous solution of sodium carbonate, sodium cyanide, and sodium hydroxide. The current was reversed for a few seconds when the specimen was placed into the plating bath, this procedure having been found to give better adherence of the deposit. The current density and plating period required for producing each thickness of plate are shown in Table 1 .

The specimens which were given very heavy deposits of chromium (Nos. 51, 52, 53, and 54) were plated under special conditions to avoid the "building-up effect" on the ends of the gages, which increases in magnitude with increased thickness of plate. The device, shown in Figure 2, was used to offset the end effect. This consisted essentially of three gages in line, the center one being the gage for test and the two end gages merely auxiliary pieces to take the end effects described. As only one end of each gage was drilled and threaded, it was necessary to use an electromagnet as shown in Figure 2, to hold the ends of the gages together. This procedure proved very effective in eliminating the end effects and in producing a uniform plate which was essential as these gages were to be tested in the condition as plated (unlapped). 
Since the gages which were to be lapped were plated uniformly, no grinding was necessary prior to the lapping operation. Wood laps were used, as these permitted the particles of chromium which were removed during this procedure to embed themselves readily in the wood, and thus scratching of the plate was avoided. When cast iron and brass laps are used, abraded particles of chromium may often project from their surfaces due to inability to embed themselves

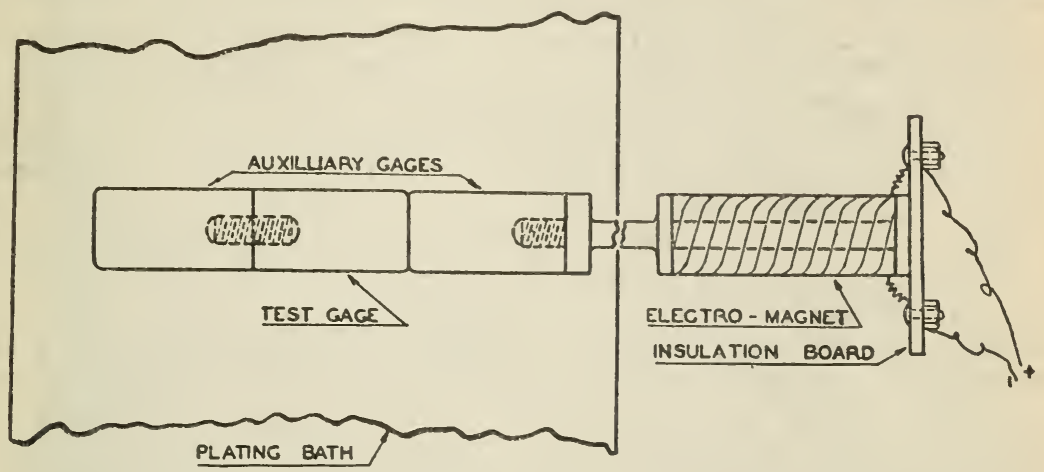

FIGURE 2.-Device used for preventing "building-up effects" on ends of test gagcs

completely, and may thus seriously injure the surface of the gage. The lapping compound consisted of a fine grade of emery, commercially used for fine finish lapping, suspended in a mixture of kerosene and oil. The gages were lapped to within \pm 0.00005 inch $(0.00125$ $\mathrm{mm}$ ) of the desired diameter.

TABLE 2.-Scratch hardness values of chromium plate

\begin{tabular}{|c|c|c|c|c|c|}
\hline Specimen No. & \multicolumn{2}{|c|}{$\begin{array}{l}\text { Plate thickness (as } \\
\text { deposited) }\end{array}$} & Type of deposit & Treatment & $\begin{array}{l}\text { Scratch } \\
\text { hardness- } \\
\text { width of } \\
\text { scratch } 1\end{array}$ \\
\hline $\begin{array}{l}22 \\
26 \\
24 \\
29\end{array}$ & $\begin{array}{l}m m \\
0.0056 \\
.0058 \\
.0074 \\
.0074\end{array}$ & $\begin{array}{r}\text { Inches } \times \\
10^{-4} \times \\
2.2 \\
2.3 \\
2.9 \\
2.9\end{array}$ & 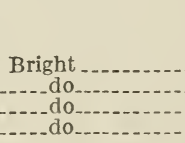 & 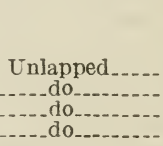 & 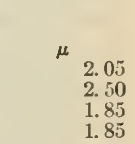 \\
\hline $\begin{array}{l}33 \ldots \\
36 \\
25 \\
27 \\
-\ldots .\end{array}$ & $\begin{array}{l}.0198 \\
.0191 \\
.013 \\
.013 .\end{array}$ & $\begin{array}{l}7.8 \\
7.5 \\
5.1 \\
5.1\end{array}$ & 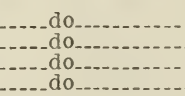 & 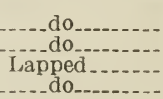 & $\begin{array}{l}2.35 \\
1.95 \\
2.15 \\
2.25\end{array}$ \\
\hline $\begin{array}{l}21^{2} \\
23^{2}- \\
15-\cdots \\
18-\cdots\end{array}$ & $\begin{array}{l}.0165 \\
.0165 \\
.0145 \\
.0216\end{array}$ & $\begin{array}{l}6.5 \\
6.5 \\
5.7 \\
8.5\end{array}$ & 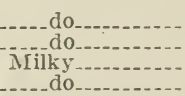 & 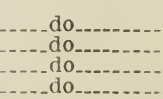 & $\begin{array}{l}1.8 .5 \\
1.85 \\
1.95 \\
1.95\end{array}$ \\
\hline $\begin{array}{l}37 \\
39 \\
11^{3} \\
12^{3}-\end{array}$ & $\begin{array}{l}.0096 \\
.0155 \\
.0081 \\
.0071\end{array}$ & $\begin{array}{l}3.9 \\
6.1 \\
3.2 \\
2.8\end{array}$ & $\begin{array}{l}\text { Frosty } \\
\text { Bright }\end{array}$ & 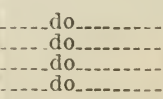 & $\begin{array}{l}1.95 \\
1.85 \\
1.75 \\
1.65\end{array}$ \\
\hline
\end{tabular}

2 These values are given to the closest $0.05 \mu$.

2 Heated to $300^{\circ} \mathrm{C}$. ( $570^{\circ} \mathrm{F}$.) for 24 hours hefore lapping, to remove occluded hydrogen.

3 Copper plate 0.0001 inch deposited beforo chromium plating. 


\section{HARDNESS TESTS}

Scratch hardness tests were made on a series of gages having chromium plate of varying thickness and appearance. The Bierbaum scratch hardness tester ${ }^{5}$ was used for this purpose. This device makes use of a sapphire, the point of which is the corner of a cube or a solid right angle and so mounted that the diagonal of the cube is normal to the surface to be tested with one edge advancing directly in the line of motion. The sapphire point is pressed against the surface of the test specimen under a $3 \mathrm{~g}$ load which is intended to steady the point and to provide pressure of the point against the surface of the test specimen. A light oil, such as watch oil, is applied at the point of contact of the sapphire with the specimen. The jewel remains stationary while the specimen is moved to produce the scratch. The width of the scratch is measured at a magnification of 500 diameters with a micrometer microscope. The results of these tests are shown in Table 2. In general, it may be said that the hardness did not vary with the thickness of the plate; nor did the variations in conditions of plating or the subsequent treatments such as heating for 24 hours at $300^{\circ} \mathrm{C}$. $\left(570^{\circ} \mathrm{F}\right.$.), appear to affect the hardness to any material degree. The hardness obtained for specimens 11 and 12, which were copper plated prior to being chromium plated, was higher (that is, the values were lower numerically) than the average results. However, the increase in hardness of these two specimens as compared with the values obtained on the other specimens was not much greater than the reproducibility of the measurements. The hardness of the "milky," "frosty," and "bright" deposits appeared to be very similar. It is quite obvious that these tests, made on a cylindrical surface, may not be quite so reproducible as those made on a flat surface.

\section{MICROSTRUCTURES}

The surfaces of all gages were examined after plating to determine the effect of thickness on the development of the so-called "strain lines" or cracks. It is generally agreed that large stresses are set up in the electrodeposition of chromium. These stresses evidently are the cause of the cracks shown in Figure 3, and reported by many previous authors. ${ }^{6,7.8}$ It is of interest to note that the size of the granular areas, or what appears to be grains, increased with increased thickness of the chromium plate. Also the number of cracks within these apparent grains appeared to increase with increased thickness of plate. These characteristics may account for the decrease in adherence which accompanies an increase in thickness of chromium plate.

3 ('hristopher H. Bierbaum, A Stuly of Bearing Metals, Trans. A. I. M. M. E., 69, p. 972; 1923.

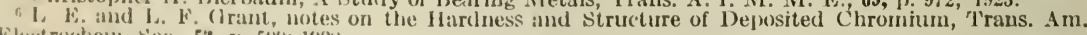
Elertrochem. soc., 53, (). 505; 1928.

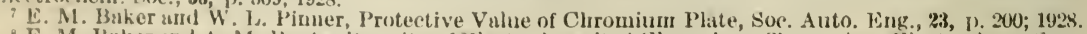

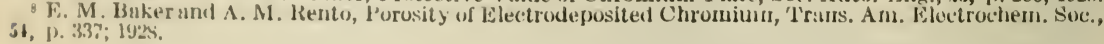




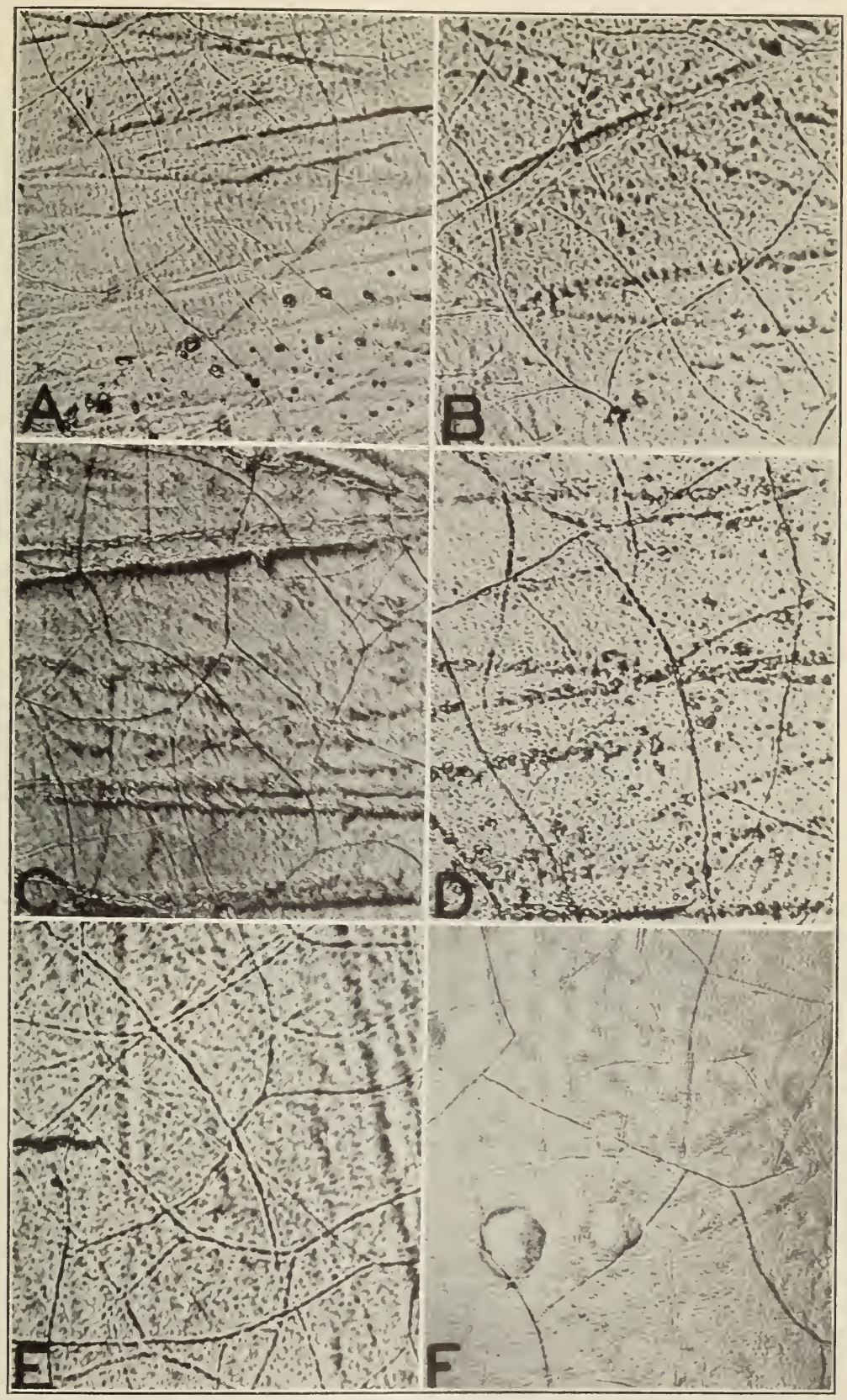

FIGURE 3.- Micrographs of surfaces of the "bright" deposit of chromium plate on hardened steel gages. (All specimens are as plated)

\begin{tabular}{|c|c|c|c|}
\hline $\begin{array}{c}\text { Speci- } \\
\text { men }\end{array}$ & \multicolumn{2}{|c|}{ Thichness of plate } & $\begin{array}{l}\text { Magni- } \\
\text { fication }\end{array}$ \\
\hline $\begin{array}{l}A(26) \\
B(24) \\
C(25) \\
D(23) \\
E(33) \\
F(55)\end{array}$ & $\begin{array}{c}\mathrm{mm} \\
0.00375 \\
.0075 \\
.01275 \\
.01625 \\
.01950 \\
.1125\end{array}$ & $\begin{array}{c}\text { Inches } \\
0.00015 \\
.0003 \\
.00051 \\
.00065 \\
.00078 \\
.0045\end{array}$ & $\begin{array}{r}\times 500 \\
\times 500 \\
\times 500 \\
\times 500 \\
\times 500 \\
\times 550\end{array}$ \\
\hline
\end{tabular}




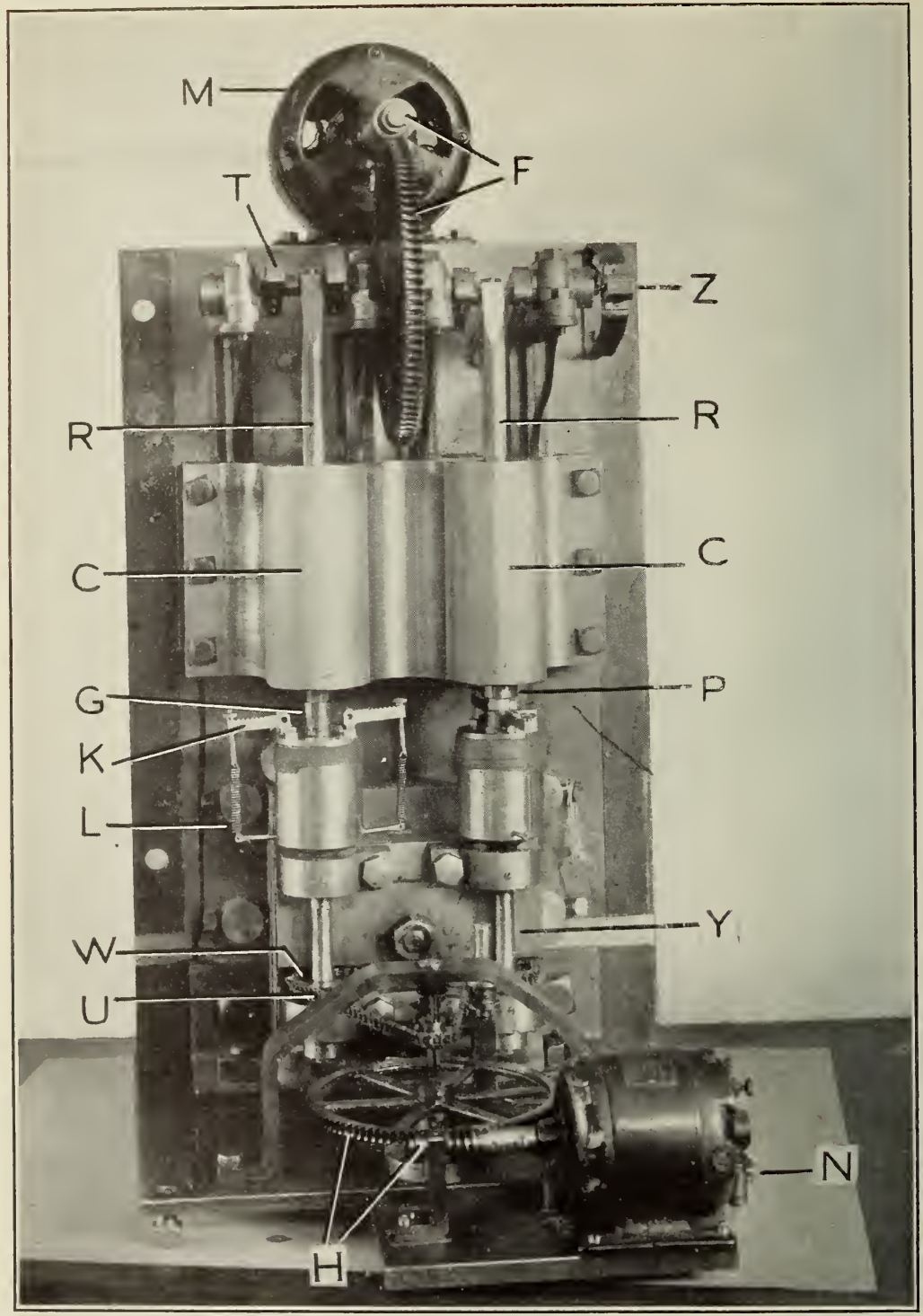

\section{Figure 4.-Gage wear tester}

The gage $G$ is moved vertically in a split ring by means of piston $P$, sliding in cylinder $C$. The piston which is driven by motor $M$ through reduction gears $F$, a connecting rod $R$ and crankshaft $T$ is threacled at its lower end to provide means for attaching test gage $G$. Motor $N$ furnishes jower which is transmitted through recluetion gears $I I$, sprocket wheel $W$, and chain $U$ to rotate split rings. The contact pressure between the gage and split ring is obtained by springs $L$ acting through lor springs $L$, arting through lever arms $K$. The holder for the split rings is in the form of a cup $\mathcal{A}$, which holds the cooling liguicl (1/13 N potassim dichromate used in these tests). The cups counter $Z$ records the number of gagings 
TABLe 3.-Resuits of wear tests on chromium-plated plug gages ${ }^{1}$

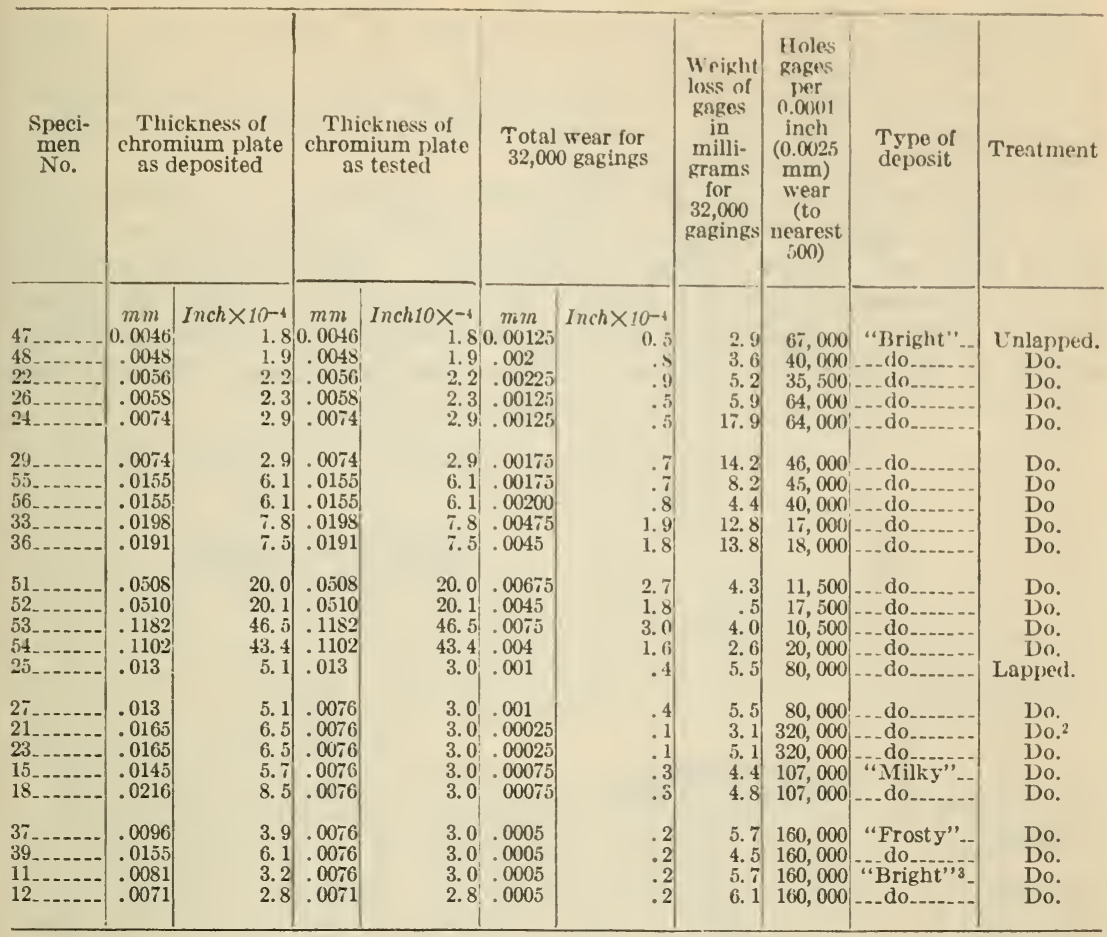

1 The chromium plate was deposited on hardened 1.0 per cent carbon steel.

${ }^{2}$ Heated to $300^{\circ} \mathrm{C}$. for period of 24 hours before lapping to remove hydrogen.

3 0.0001 inch copper plate deposited before chromium plating.

\section{RESISTANCE TO WEAR}

\section{TESTING PROCEDURE}

The tests for wear resistance were made on a special gage-wear tester shown in Figure 4 which was designed and constructed by the bureau. This is essentially a machine for repeatedly inserting plug gages into split rings, which represent the material to be gaged. An accurate control of the important variables which affect the rate of wear, such as pressure between the gage and the work, the presence or absence of abrasives, lubricants, etc., can be obtained with this machine as well as control of the metals from which both gages and material to be gaged are made. This machine was designed so that its operation would simulate closely the service operation of a plug gage. The split rings were made of "pearlitic" cast iron which was selected because of its high abrasive action on most materials against which it is used. A constant pressure of $22 \mathrm{lbs} . / \mathrm{in} .^{2}\left(1.5 \mathrm{~kg} / \mathrm{cm}^{2}\right)$ was maintained between the gage and ring and all tests were made under conditions of "metal-to-metal" wear. A 1 per cent solution of potassium dichromate was used to prevent "filming" due to oxidation of the gages and rings. A complete test on a gage consisted of 8 runs of 4,000 gagings each. The loss in weight and decrease in diameter were determined after each run. Similarly the losses in weight of the rings were noted. 


\section{RESULTS AND DISCUSSION}

The results of the wear tests are listed in Table 3 and shown graphically in Figure 5. The values used in Figure 5 were computed on the basis of the number of holes gaged for a reduction in diameter of the gage of $0.0001 \mathrm{inch}$, in order to give a standard basis of comparison for the various gages tested.

Although gages 21 and 23 appear to be decidedly superior to all other gages tested, it should be realized that these values are computed from very small changes in diameter. Thus, the average total loss in diameter of gages 21 and 23 was 0.00001 inch, while on gages 37 and 39 the average total loss was 0.00002 inch. As these losses approach the limit of accuracy of the measurements, the relative differences in wear may not be so great as appears.

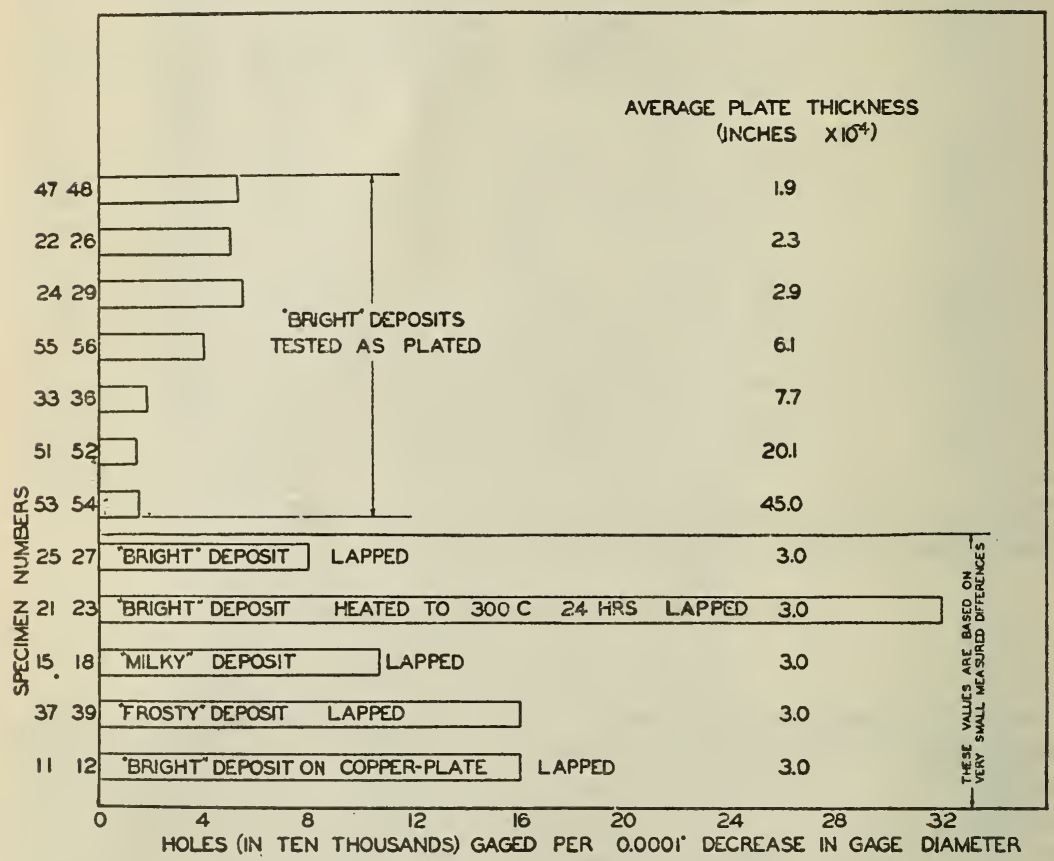

FIGURE 5.-Results of wear tests on chromium-plated plug gages

The unlapped gages showed considerably lower resistance to wear than did the lapped gages. The resistance of the unlapped gages to wear decreased as the thickness of chromium plate was increased. The inferiority of the unlapped gages can be accounted for by the "peaks" or low undulations, microscopic in character, which develop as the plate is deposited. These "peaks" or wave-like surfaces, which are readily observed under the microscope, become more pronounced as the thickness of plate is increased. It can readily be seen that such a surface will wear more rapidly than an initially smooth surface, or one from which these irregularities have been removed by lapping. It will also be recalled that the cracks in the deposit increased with increased thickness, which indicates that the internal stress increased as the plate thickness was increased. The greater the internal stress, 
the more readily will failure occur when external stress is applied. Hence, the heavier deposits would be expected to offer less resistance to the tearing off of particles than the thinner deposits. 'The experimental results have shown that this actually takes place.

The "frosty" and "milky" deposits of chromium plate (lapped) show higher resistance to wear than the "bright" deposits (lapped). The "milky" and "frosty" deposits were tested in the lapped condition only. The "bright" deposits (lapped) appeared to give improved wear resistance when heated to $300^{\circ} \mathrm{C}$. $\left(570^{\circ} \mathrm{F}\right.$.) for 24 hours prior to lapping. This treatment, which is known to expol occluded hydrogen, reduces the brittleness of chromium plate and increases its toughness. This change would be expected to give increased resistance to wear. ${ }^{9}$

When a copper plate was applied prior to the deposition of "bright" chromium plate, the hardness of the chromium plate was apparently increased. Higher scratch hardness readings were obtained on such surfaces than on a similar plate applied directly to the steel base. This procedure also resulted in an improved wear resistance. This improvement indicates that the chromium deposited on copper was harder and tougher than that deposited directly on steel. Another possible advantage of the thin copper layer is that it might, by its appearance, facilitate the detection of the wearing through of the chromium at any point.

Referring to Table 3 , it will be seen that the weight losses are not entirely consistent with the losses in diameter. This is due to the fact that the surfaces of the plated, unlapped gages are "wave like" as previously explained. When wear occurs, the tops of the undulations may be worn off, causing a large decrease in diameter without a corresponding decrease in weight. On the other hand, a deep scratch or a small chipping of the plate may cause a high weight loss and yet effect no change in the measured diameter.

Comparison of the results of this research with those of the previous study, shown in Figure 1, indicates that although there may be relatively large differences in the wear resistance of chromium deposited under different conditions, practically all the chromiumplated gages are superior to any of the other gages used in the former investigation. The present series of tests, however, were not extensive enough to warrant any general recommendation concerning the use of chromium-plated gages for "any and all" purposes as a replacement of ordinary hardened steel gages. For example, the results obtained on plug gages may not necessarily be applied to thread, snap, or ring gages. Furthermore, the element of cost must be considered for each particular type of job.

\section{SUMMARY}

1. A series of chromium-plated plug gages were tested for hardness and resistance to wear. The chromium deposits were prepared under varying conditions of current density, temperature, and time of plating. Some of the gages were lapped after plating, others were tested as plated.

- A similar heat treatment has been recommended to increase the corrosion resistance of chromium coatings. R. J. Wirshing, Heat Treatment of Chromium Depusits to lncrease Their Resistance to Corrosion, Trans. Am. Electrochem. Soc., 53; 1930. 
2. Within the limits used in the chromium deposition, no material differences were observed in the hardness of the chromium plate deposited directly on steel.

3. Microscopic examination revealed an increase in "strain lines" or cracks in the surfaces of the chromium plate with increased thickness of the deposit.

4. The wear resistance of unlapped chromium plate decreased with increased thickness of the plate.

5. The wear resistance of chromium plate which had been heated to $300^{\circ} \mathrm{C}$. $\left(570^{\circ} \mathrm{F}\right.$.) to drive off occluded hydrogen and subsequently lapped, was greater than for plate similarly deposited and lapped, but not subjected to heat treatment.

6. Chromium plate deposited under such conditions as to produce "milky" and "frosty" deposits, respectively, and subsequently lapped, showed somewhat higher resistance to wear than "bright" deposits of chromium which were also lapped.

7. Gages which were initially copperplated and then chromium plated and lapped showed about the same resistance to wear as the gages with lapped "milky" and "frosty" deposits, but were superior to the gages with "bright" deposits applied directly to the steel.

\section{ACKNOWLEDGMENTS}

The author is indebted to William Blum, of this bureau, for his many valuable suggestions in the course of this investigation, to G. E. Renfro, of this bureau for plating all the gages used in this investigation and to Pratt \& Whitney Co., Hartford, Conn., who machined and lapped the carbon steel bases upon which the chromium was deposited.

Washington, December 19, 1930. 